\title{
Corporation and Contract
}

\author{
Henry Hansmann, Yale Law School
}

Publicly traded corporations rarely use the nearly absolute freedom afforded them to draft charters that deviate from the default terms of state corporation law. Conventional explanations for this phenomenon are unconvincing. A more promising explanation lies in the lack of any feasible amendment mechanism that will assure efficient adaptation of charter terms as changing circumstances dictate during the long expected lifetime of a public corporation. In effect, by adopting state law default terms, corporations delegate to the state the process of amending charter provisions over time.

The great bulk of corporate law deals with relationships among the owners and managers of firms. These relationships are, at bottom, contractual, in the sense that the parties involved enter into them voluntarily and they do not directly affect third parties. This leads one naturally to ask why we need rules of law to govern these relationships. Why is corporate governance a matter of law, rather than of contract?

The conventional wisdom today is that the internal affairs of business corporations are, in fact, almost completely contractual. Most of the provisions in business corporation statutes are just default rules. If an alternative is desired, it can simply be put in the corporation's charter, displacing the

This essay was originally presented as the presidential address at the May 2004 annual meeting of the American Law and Economics Association. For helpful comments and discussions, I would like to offer special thanks to Barry Adler, Robert Daines, Jeffrey Gordon, Zohar Goshen, Edward Iacobucci, Marcel Kahan, Michael Klausner, Lewis Kornhauser, Reinier Kraakman, Yair Listokin, Paul Mahoney, Larry Ribstein, Barak Richman, and George Triantis.

Send correspondence to: Henry Hansmann, Augustus E. Lines Professor of Law, Yale Law School, 127 Wall Street, New Haven, CT 06511; Phone: 203-4324177; E-mail: henry.hansmann@yale.edu.

American Law and Economics Review doi:10.1093/aler/ahj007

Advance Access publication March 17, 2006

(C) The Author 2006. Published by Oxford University Press on behalf of the American Law and Economics Association. All rights reserved. For permissions, please e-mail: journals.permissions@oxfordjournals.org 
statutory provision. As a consequence, either these provisions are inconsequential (Black, 1990), or they have at most a modest influence. The reasons why default rules might have some influence include the transaction costs of drafting and negotiating, the high salience or presumptive legitimacy of governmentally provided terms, the need for standardization, and the burden of deviating from information-forcing "penalty defaults."

There is surely some truth in these views. I believe, however, that the conventional wisdom understates both the degree of contractual freedom facing business firms today and the rarity with which that freedom is exercised, and as a consequence understates, as well, the great influence exercised by corporate law's default rules, particularly on publicly traded firms. More important, I believe that there is a better explanation than those conventionally offered for the strong influence exercised by the default rules of corporate law. The essence of this explanation is that, by adopting default rules of law rather than using explicit contracting, parties allow for the constant readjustment of their relationship over the long period of time that it may last. The provisions of corporate law are essentially contract terms that can be repeatedly reformed by a third party - the state - to adapt them to changing circumstances. Thus, paradoxically, the great advantage of law over contract in organizing corporations is that rules of law are more easily changed. This theory provides much stronger reason for deferring to the law's default rules than do the other theories that have been offered. It implies that default rules may often be nearly as influential as mandatory rules, and that scholars are not wasting their time debating whether one rule of corporate law is more desirable than another even if, as is typical, the rule chosen will be formulated only as a default.

\section{The Extreme Contractualization of Corporate Forms}

Even more than is commonly realized, virtually all of corporate law today consists of default rules rather than mandatory rules.

When the corporate form became widely available in the latter part of the nineteenth century, it was relatively inflexible. To have the benefit of limited liability and freely tradable shares that it offered, an organization had to adopt a relatively rigid structure. Over the succeeding century and a half, the corporate form was gradually liberalized to permit increasing freedom in tailoring the allocation of earnings and control. And now, over the past 25 years, we have achieved even greater liberalization with 
four newly established limited liability forms: the limited liability company (LLC), the limited liability partnership, the limited liability limited partnership, and the statutory business trust. These new forms permit creation of a full limited liability entity, without the remaining rigidities of the business corporation statutes. ${ }^{1}$

In this regard, the statutory business trust, first adopted in Delaware in 1988 , represents the conceptual endpoint. It offers virtually complete contractual freedom with respect to assignment of earnings, control, and even fiduciary duties. In fact, the form does not even offer default terms for most matters; nearly everything is left to the firm's creators, to be specified in the firm's governing instrument (Hansmann and Mattei, 1998; Sitkoff, 2005).

This progressive liberalization seems best understood as the consequence of an increasing ability to protect both creditors and equity investors by contractual means rather than by reliance on organizational constraints (Hansmann, Kraakman, and Squire, forthcoming). It is the result of a variety of developments in fields such as bankruptcy law, tax law, accounting practices, credit reporting services, communications, calculating technology, and commercial contracting. Much of this increased flexibility in corporate law was originally focused on small firms. For example, the special provisions for close corporations in Delaware's corporation law were, and still are, limited to firms that have no more than 30 shareholders.

The four new forms of the past 25 years, however, are not confined to closely held firms. Rather, the nearly limitless contractual flexibility they offer is available to publicly traded firms as well. The result is that, in substance, all mandatory terms in state corporate law have now been eliminated. Today, if a firm wants the full limited liability and publicly tradable shares of a business corporation, and also wants access to Delaware's famous chancery courts, but wishes at the same time to avoid some of the remaining mandatory elements of Delaware corporation law, the firm can simply form as a Delaware LLC or Delaware business trust. Virtually all rules of Delaware's general corporation law are, consequently, now just default rules. The remaining mandatory constraints on the corporate form are just those to be found in federal securities law or in the stock exchange listing rules.

1. The evolution of these entities is described in Hansmann, Kraakman, and Squire (2005) and Hansmann, Kraakman, and Squire (forthcoming). 
These developments might suggest that corporate structure in general, including the structure of publicly traded firms, is becoming an increasingly contractual subject, with ever greater delegation to the actors directly involved - that is, to investors and managers - of responsibility for the design of intracorporate relationships. In fact, one might go further and wonder why, now that we have the statutory business trust, we need any of the other statutory forms at all. The business trust provides the only attributes of a firm for which law is truly essential-namely, the rules governing the rights and expectations of third parties, including particularly the rules of asset partitioning that govern creditors' rights and the related rules of agency law that govern the authority of corporate actors to make commitments that bind the firm (Hansmann and Kraakman, 2000). In principle, everything else-all matters of internal relationships—can be handled by contract. So it seems that there is nothing that one can do with a business corporation statute, or with the three other new statutory forms, that cannot also be done with the business trust. All that is required is some additional drafting.

\section{The Paucity of Corporate Contracting}

Yet the extraordinary freedom that is now available to the drafters of corporate charters is exploited in remarkably small degree. While closely held business firms commonly have detailed, specifically tailored charters, the charters of publicly traded corporations are remarkably empty. They are commonly just a few pages long and contain very little of interest. They effectively defer to the default terms of the state corporation law in virtually all matters of significance. If they contain anything else at all, it generally involves one or more of a few simple standardized deviations of a general character - such as provision for a staggered board or for dual class stockthat entail choosing well-established alternatives from the statutory menu. We do not see corporate charters trying out any of the big reforms that are routinely pressed today, such as takeover rules along the lines of the British City Code, or expanded shareholder nomination rights, or constraints on the structure and disclosure of executive compensation. ${ }^{2}$

2. I base this qualitative observation, in part, on examination of a sample of corporate charters generously shared with me by Michael Klausner and collected in the course of his work with Robert Daines. See Daines and Klausner (2001). 
Meanwhile, the statutory business trust has not, in fact, been used for interesting experiments with publicly traded firms. Rather, it has been used almost exclusively for just two standardized purposes: asset securitization and formation of mutual funds. In fact, the uses of the business trust have been so unimaginative that, in the 17 years since Delaware first enacted its business trust statute, there has apparently been only one reported decision interpreting that statute (Sitkoff, 2005, pp. 38-39).

\section{Why Not More Contractualization?}

Why do the terms of corporate charters follow the statutory defaults so closely? Although the reasons conventionally offered surely have some weight, they seem quite inadequate to explain the phenomenon in full. To illustrate, I review briefly the most familiar of those reasons.

\section{Transaction Costs of Drafting Are High}

The most commonly offered argument for default terms, in corporate law as in other forms of contracting, is that they economize on the transaction costs of drafting (Easterbrook and Fischel, 1989, p. 1444). This might explain why some small closely held corporations defer to default rules, but it seems extraordinary to believe that the transaction costs of drafting could be an important consideration for the charters of publicly held firms (Ayres, 1992, p. 1397). Yet it is closely held firms that have customized charters and publicly held firms that hew slavishly to the defaults.

\section{Charter Terms Are a Public Good}

A related argument for the dearth of privately crafted corporate charter provisions is that innovation in charter terms is a public good, and that consequently it is not worthwhile for private actors to incur the expense of developing innovative terms (Easterbrook and Fischel, 1989, pp. 1445-46).

But this is entirely unpersuasive. Drafting charter terms is not all that expensive. Lawyers routinely draft complex new documents for all sorts of purposes, many of which - such as those involved in asset securitizationform the basis for publicly traded securities and are easily subject to copying by others. Most conspicuously, the public goods problem has not prevented development of private standard forms for bond indentures, 
nor has it prevented regular innovation in those forms (see Kahan and Klausner, 1993). What is more, some organizations have even established property rights in standard contract forms and make money from selling them. The American Institute of Architects, for example, sells construction contracts that they have developed and keep up to date, and that have become the industry standard (Davis, forthcoming).

\section{Network Effects Compel Standardization}

Klausner (1995) has argued that the default rules of corporate law gain much of their force from the need for standardization that derives from network effects (see also Kahan and Klausner, 1997). These third-party network benefits include the greater certainty that derives from judicial interpretation of similar terms in other firms' charters, the reduced cost of legal services resulting from a focus by lawyers on a narrower range of terms, and the lower costs to prospective investors in evaluating alreadyfamiliar terms. While these benefits could presumably be achieved by adopting privately drafted standard forms, law has the advantage, under this view, of providing a conspicuous focal point that facilitates choice of the common standard (Klausner, 1995, p. 828).

There is surely some force to this theory. But there are reasons to doubt that it provides a satisfactory explanation for the dominant role of law in structuring the internal affairs of corporations. For one thing, it seems to exaggerate the demand for uniformity. The stock market has, for instance, happily accepted firms with unusual internal structures. To take one conspicuous example, in 1994 United Air Lines was reorganized to give majority voting control to its employees. Though it was a Delaware corporation, the structure of control and earnings rights embedded in the company's new charter was extremely unorthodox and highly complex, with a variety of novel means for selecting directors, odd committee structures on the board, numerous classes of stock with extremely unorthodox rights and restrictions, and dramatically shifting contingent relations between share ownership and voting rights. ${ }^{3}$ Yet stock in the reorganized firm was enthusiastically embraced by the markets and remained one of the darlings of Wall Street for several years afterward.

3. For a brief summary, see Hansmann (1996, pp. 117-18). 
Moreover, the theory that the requisite standard form charter terms must be provided by law, rather than by privately provided standard forms because law offers a powerful focal point, also seems difficult to reconcile with the evidence. In particular, the focal point theory of the role of law does not distinguish well between those areas in which standard form terms are provided by law, as they are in the internal affairs of publicly held firms, and those areas in which the standard form terms are privately provided, as they are in bond indentures.

\section{Innovative Terms Will Not Be Priced}

A closely related argument is that the market is incapable of pricing particular legal terms in a corporate charter, either for of lack of ability, or for lack of attention. Consequently, design of the charter cannot be varied freely in individual cases.

If this explanation were true, it would throw serious doubt on the efficiency of the securities markets. But there is good evidence that it is not true. For example, indentures for corporate bonds run to scores or even hundreds of pages, and often contain complex covenants restraining the actions of corporate managers. Yet these bonds commonly trade freely, and there is good evidence that the securities market prices their terms with reasonable efficiency (Kahan, 1995, pp. 574-80).

\section{Statutory Terms Are Penalty Defaults}

Ayres and Gertner (1989) have argued persuasively that many default rules for contractual relations serve as information-forcing "penalty defaults" that, by burdening the better-informed party to the transaction, face that party with the choice of accepting the burdensome default or revealing to the other party information that will be helpful in achieving alternative terms that are fair and efficient. Depending on the tradeoff of costs and benefits involved, the incentive to deviate from these terms might often be modest.

Yet many of the rules of corporate law do not seem structured as penalty defaults. Indeed, if anything, United States corporate law seems to have a distinct managerialist tilt, with the consequence that deviation from the default rules would presumably be in the direction of favoring dispersed 
shareholders, who are presumably the least-informed parties to the corporate contract. Moreover, penalty defaults would not be having their intended effect if they were to discourage all deviation from the standard terms.

\section{The Need to Modify Relational Contracts}

Why, then, do we observe such a radical scarcity of private contracting in the charters of publicly held corporations? The reasons are surely complex. But the evidence suggests that the most important reason lies in the need to modify charters over time.

Publicly traded business corporations often have very long lifetimescommonly scores of years, and sometimes hundreds. Changes in the firm and in the surrounding society are highly likely to call for occasional changes in the firm's internal relationships. If these relationships are fixed by the firm's original charter, obsolescence will be the result. But if the firm's charter is instead provided by law, it is potentially much more flexible. The legislature or the courts can simply change the law to adapt.

A prototypical example is the shareholder vote required to approve a merger. Before 1963 the default rule in Delaware, as in other states, was two-thirds of the outstanding shares of stock. In that year the default-and the mandatory minimum - was dropped to a simple majority. That change was arguably efficient in light of contemporary changes in shareholding patterns, the greater efficiency of market institutions, and the increasing need that new technologies brought for recombinations of corporate assets. But if the merger rules had been embodied in corporate charters rather than in Delaware law, many corporations would have been stuck with the anachronistic two-thirds supermajority vote requirement, which could not be changed without the same supermajority vote.

Of course, as the example of the merger vote suggests, all of this depends on the mechanisms available for amending the corporate charter. There are various mechanisms employed in different jurisdictions, but all of them require, at some point, a vote of approval by the shareholders. And it is hard to conceive of a charter amendment mechanism that would not involve such a vote. Yet it is a familiar fact that there is no simple voting rule that assures an efficient choice.

In the U.S. a company's board of directors must propose charter amendments, presumably to mitigate some of the pathologies of pure 
shareholder democracy. Yet the managerial veto fails to cure all the problems with shareholder voting-most obviously, because the directors themselves are elected by the shareholders-and adds some obvious problems of its own, including aggravation of the managerial agency problem. Nor does the market for corporate control solve the problem, since it, too, ultimately depends on the internal political mechanisms of the firm.

In short, if charters are made hard to amend, they threaten to lock in bad terms or to give holdup power to one group or another, whereas, if they are made easy to amend, there is too much room for opportunism or ignorance on the part of either shareholders or managers. The ultimate problem for corporate structures, then, is one of politics - the internal politics of the firm. The limitations of collective choice mechanisms render them inadequate to assure efficient adaptability of a corporation's structure over time.

\section{The State as Reviser of Contracts}

Given this problem, there are potential advantages to delegating to a third party the responsibility for adjusting, as time and circumstance require, the terms of the basic contract among a company's shareholders and managers. The state serves as that third party. Through statutory amendments or judicial decisions, the state can, in effect, alter the corporate charter when the need arises. By accepting the statutory defaults, shareholders and managers delegate to government the task of revising their contractual relations over time.

There are, of course, difficulties with this form of delegation: the state may have purposes of its own unrelated to the efficient organization of enterprise, the relevant state actors may not always be well informed, and the result may be excessive standardization of the corporate form. I will say more about these problems shortly. The relevant consideration, however, is that reliance on corporations themselves to adjust their charters over time may give rise to even greater problems. Consequently, purchasers of corporate securities in widely held firms might reasonably prefer that corporate charters accept statutory default terms simply to get the flexibility that comes with state-provided terms.

This is not a novel theory about the role of law. Oliver Williamson (1976), for example, argued long ago that public utility regulation serves to provide the necessary adaptive governance structure for long-term 
relational contracts that require continuous readjustment. I am simply observing here that the relations within a corporation are also long-term relational contracts, and hence it is reasonable that the best governance structure for these contracts is, in effect, the government. ${ }^{4}$,

\section{Does the Theory Fit the Facts?}

Can we, however, be certain that the need for adaptability is an important reason that publicly traded corporations so consistently defer to the default terms of corporate law? Evidence in favor is that the proposition is broadly consistent with the pattern of corporate chartering that we see. Corporations that reject the statutory default terms in favor of elaborately crafted special charter provisions typically exhibit either or both of two characteristics. First-as in the case of many small firms with elaborately specialized rights involving board positions, employment rights, and withdrawal or sale of shares - the firms have a small number of owners who can renegotiate the corporate structure among themselves with reasonable efficiency if substantial changes are called for. Second, as in the case of venture capital financed high-tech startup firms, they have a relatively short expected life, limiting the risk that the initial corporate structure will need adjustment before the firm is dissolved or reorganized along more conventional lines.

Consider also, in this respect, the only two uses commonly made of the business trust, with its dearth of default rules. One of these uses is the formation of mutual funds, which are publicly held and have indefinitely long lives. The principal governance terms of mutual funds are not specially crafted, however, but simply taken from a different statute: the Investment Company Act of 1940. The other use of the business trust, asset securitization, does in fact employ detailed privately drafted governing instruments. But the entities are used to support debt securities that have relatively short lifespans, at the end of which the entities are dissolved. Similarly, the detailed covenants in junk bond indentures need only serve for the fixed life of the bonds involved.

4. See also Gordon (1989, pp. 1573-1585) who presents a related theory in the context of corporate law, though he focuses on a justification for mandatory rules of corporate law rather than default rules. His argument is, in rough summary, that the available mechanisms for avoiding opportunistic amendment of corporate charters are so inadequate that there may be efficiency gains from making some rules - particularly those constraining insiders - mandatory, and then relying on the legislature, rather than corporate actors themselves, to change those rules when needed. 
And what about United Air Lines, which, as already noted, was warmly received by the public stock markets even with a highly tailored charter? It is in fact consistent with the general pattern described here, since its original charter terms were not designed to govern the firm indefinitely. Rather, the elaborate and idiosyncratic provisions in that firm's 1994 charter were designed from the outset to sunset within no more than 20 years, after which the firm would return to a conventional governance structure.

Another exception that proves the rule is that, as was famously discovered by Daines and Klausner (2001), a large proportion of companies newly going public put antitakeover provisions in their charters rather than defer to the statutory default rules in this area. These initial public offering charters do not actually contain what one would properly call antitakeover provisions. They do not, for example, explicitly require prior approval from the board of directors before specified types of control transactions can take place. Rather, they typically provide for such things as staggered boards, dual-class stock, authority to issue blank check preferred stock, or a prohibition on the ability of shareholders to act by written consents. It is the decisional law of Delaware (and other states) that says, in companies that have these features, managers can exercise broad authority to prevent hostile takeovers. But the scope of this authority is being continually expanded and contracted by the courts, and could quickly be sharply constrained if the courts or the legislature ever saw fit to do so. As a consequence, it is perhaps not a great puzzle that institutional investors are willing to buy the stock of companies with these so-called antitakeover provisions in their charters. These investors are just buying into one of several standard statutory defaults that are always subject to amendment by the state. If, instead, these investors were confronted with a real antitakeover provision that was seriously embedded in the charter, they might be much less eager to invest. ${ }^{5}$

5. The experience with tracking stock in recent decades might also be read as a reflection of the market's resistance to specially crafted terms in public company charters. Despite concerted efforts by investment banks to persuade companies to issue tracking stock, very few firms adopted these securities with their novel distinctions between the allocation of governance rights and the governance of rights to net earnings. It might be argued, however, that the resistance to tracking stock was largely based, not just on the possibility that it would lock firms into arrangements that might someday prove both troublesome and difficult to alter. It was also based on the fact that, right from the outset, tracking stock created such conspicuous and unmanageable conflicts of interest within the issuing firms that it was very unlikely to increase aggregate firm value. See generally Hansmann (1996, pp. 63-64). 


\section{Further Empirical Evidence}

The delegated contracting theory offered here gains further support from a valuable systematic study of the impact of corporate law default rules undertaken by Yair Listokin (2005). Of particular relevance are Listokin's findings concerning statutory fair price provisions, which are a species of antitakeover rule that impedes two-tier takeovers in which the price paid in the first-step tender offer is higher than the price paid in the second-step freeze-out merger. ${ }^{6}$ Between 1983 and 1991, 27 states enacted fair price statutes. Three states made the statutory rule mandatory. Twenty-three states adopted provisions allowing companies to opt out of the rule, either by charter amendment (10 states), or by bylaw amendment (13 states). And one state, Georgia, required companies to opt into the statutory fair price provision (see Table 1).

Listokin (2005) focuses principally on possible explanations for the difference between opt-in states and opt-out states-the difference between the figures in row 2 and those in row 3-regarding the frequency with which companies adopted fair price provisions. Of most importance here, however, is the difference in the rate of adoption of fair price provisions between companies in states with no fair price statute (row 1) and the state (Georgia) with an opt-in statute (row 2). The adoption rate in Georgia is almost 3 times as high for companies overall and 6 times as high for companies newly going

Table 1. Rate of Adoption of Fair Price Provisions in Charter

\begin{tabular}{lcc}
\hline & $\begin{array}{c}\text { All } \\
\text { Companies }\end{array}$ & $\begin{array}{c}\text { Companies Going Public } \\
\text { after Passage of the Statute }\end{array}$ \\
\hline 1. Companies in states with no statute & $20.4 \%$ & $9.5 \%$ \\
2. Companies in opt-in state (Georgia) & $56.4 \%$ & $57.1 \%$ \\
3. Companies in opt-out states & $98.4 \%$ & $97.0 \%$ \\
\hline
\end{tabular}

Notes: Listokin (2005, Tables 3 and 5).

6. Listokin's article also reports rates of adoption for two other types of antitakeover devices that can be adopted in some states by either opting into or opting out of specially designed statutory provisions: control share acquisition statutes and business combination statutes. For lack of data, however, he could not report the frequency with which corporations adopted charter provisions with similar properties in states that did not have specific statutory provisions of these types. 
public. Listokin suggests briefly-consistent with the conventional wisdom-that these differences may reflect the additional costs of drafting and negotiating a fair price charter provision that must be incurred in states without an opt-in statute (Listokin, 2005, p. 34). But it is hard to imagine that these costs could explain the difference. All management-or rather, management's lawyers-need do is copy one or another of the state statutory provisions, or another company's charter provision.

Perhaps there is also a legitimation effect from an opt-in statute: both managers and shareholders may feel more comfortable enacting a charter amendment if it has been blessed beforehand by the relevant state corporation law. But a more logical justification for the difference-and one that is perhaps influencing the choices of the lawyers, managers, and shareholders involved-is that a specially crafted charter provision is locked in until the charter is again amended to remove it (or alter it, or make other charter amendments that become appropriate to tailor its effects), whereas a provision in the state's corporation statute can be altered as necessary over time by the state's legislature and judiciary to keep it consistent with changes in circumstances and in other aspects of the state's corporation law.

\section{Default versus Mandatory Terms}

The delegated contracting theory of corporate law offered here has the ironic implication that the most heavily regulated organizational forms may be, in the long term, the most adaptable. Most publicly traded business corporations, with their vacuous charters, are subject to the ever changing governance rules promulgated by the Delaware legislature and courts—rules that, it is frequently argued, in fact seem to change rather too often. In contrast, firms with detailed, privately crafted governing instruments are potentially rather rigid, capable of structural change only by securing the acquiescence of both shareholders and managers to a formal amendment of the charter.

It makes no difference in this respect whether the rules of corporate law involved are mandatory or default rules. Both are equally subject to adjustment by the state, and potentially more adaptable than provisions embedded in a corporate charter. Moreover, so long as - to take advantage of the benefits of delegated contracting-publicly traded corporations routinely defer to virtually all terms of the corporation statute, those terms may as well be mandatory. In short, the difference between mandatory and default 
terms of corporate law may often be of little significance, not because, as Black (1990) argued, mandatory rules are nearly as easy to avoid as default rules, but because the incentives for deferring to default rules are sufficiently strong to make them nearly as unavoidable as mandatory rules.

\section{Why Government?}

If government is playing the role of delegated third-party contracting agent for corporate investors and managers, it is natural to ask whether that role might alternatively be played by a private actor. Might a corporation instead choose a law firm for that role, or perhaps a nonprofit trade association? Indeed, in the United Kingdom, the nongovernmental City of London Panel on Takeovers has set the terms for some of the most important aspects of corporate governance for the last 40 years.

Evidently, what is needed for the role of delegated contracting agent is an institution that has substantial expertise, that has an interest in keeping the terms of corporate charters reasonably efficient, that can be counted on to last indefinitely, and that will remain relatively free from regulatory capture by one or the other corporate constituency. The state of Delaware fits this role well, for a number of familiar reasons (Romano, 1993). In particular, it is a small state that is not heavily industrialized and, consequently, contains very few of the shareholders or companies whose affairs it regulates, making the state essentially a third party in relation to those interests. It may be difficult for a private organization to achieve similar independence from the interested parties. For example, private arbitration has never played a large role in resolving intracorporate disputes in the U.S. perhaps because arbitration works best where, as with commercial contracts, the parties to disputes are more symmetric and there is less reason for concern that the institution will have a systematic bias toward one side or the other (Dammann and Hansmann, 2005). ${ }^{7}$

\footnotetext{
7. Hadfield and Talley (2004) offer reasons that, if private providers were otherwise as capable as public entities of providing corporate law, competition might lead to more efficient provision of law, if the providers were private firms rather than elected governments. However, their model does not focus on the particular characteristics of corporate law as being applicable to public versus private provision of private goods in general.8.Klausner (1995, pp. 837-41) also thoughtfully explores, in the context of his network theory, the potential for a single state to offer firms choices among alternative corporate law rules.
} 
We see here the difference between the delegated contracting theory of corporate law and the network externalities theory. Under the latter theory, network interdependencies give corporations an incentive to choose common charter terms, and public provision of those terms is useful because it provides a strong focal point to coordinate choice. Under the delegated contracting theory offered here, in contrast, corporate charters must be subject to substantial amendment over time, and public institutions-legislatures and courts-have an advantage in providing those amendments because they can serve as relatively durable and trustworthy third parties that, though highly imperfect, avoid some of the conspicuous defects of the available mechanisms for charter amendment within corporations themselves. While this process of public amendment might work with privately drafted charter provisions, courts and legislatures will appropriately give much greater deference to private than to public (statutory and judge-made) provisions, hence rendering private provisions more inflexible and providing an incentive for firms to defer to the publicly provided terms-an incentive that would be present even absent network economies from having corporations choose similar terms for their charters. The two theories are, however, complementary and interrelated.

\section{Inter- versus Intrajurisdictional Choice}

The analysis offered here suggests that the governance of publicly traded firms will continue to be determined by the default terms of corporate law rather than by contract. It does not necessarily imply, however, that there need be a unique set of default terms. There can be choice among sets of default rules. Thist kind of choice has, of course, been the focus of the extensive debate on regulatory competition in corporate law, which has concerned itself with the alternatives offered by different jurisdictions and with the appropriate degree of freedom of choice across jurisdictions.

Intrajurisdictional choice is also a possibility, however, and in some ways a more promising one. ${ }^{8}$ Suppose, for example, that some state (say, Maryland) were to develop a corporation statute that offered a real

8. Klausner (1995, pp. 837-41) also thoughtfully explores, in the context of his network theory, the potential for a single state to offer firms choices among alternative corporate law rules. 
alternative to Delaware's - perhaps more proshareholder, more promanagement, or more efficient in some other respect-and were to begin attracting corporations away from Delaware in significant number. What would keep Delaware from copying Maryland's statute, while also retaining its own preexisting statute for the sake of those firms that still prefer it?

Put more generally, what is to prevent Delaware itself from offering a full set of competing corporation statutes and allowing companies to choose among them? After all, the real competition here is between forms, not between states. Delaware might offer, for example, a shareholderoriented statute with extensive rights for shareholders to nominate and elect all directors annually, and with the British City Code rules inhibiting defensive tactics in takeovers. At the same time, as an alternative choice, Delaware might offer a more managerial statute that provides for, say, a self-perpetuating board, more or less along the lines of the European industrial foundations (Thomsen, 2004). And perhaps it might offer a third form in between, something like what we have now. Each form could then be updated regularly by statute and judicial decision to maintain its basic character without letting it become obsolete. In short, if, as some have convincingly argued, Delaware is effectively the only state that is competing for charters (Daines, 2002), perhaps it can start competing with itself.

This is essentially what Delaware has done with respect to closely held firms. In a conspicuous effort to remain attractive to business, Delaware has recently adopted, as we have noted, four new statutes for such firms. Added to its existing close corporation statute, it now has five different statutory forms suited for closely held firms. These statutes overlap substantially, and are to a considerable extent redundant. But, evidently because some firms might have a preference for one set of default terms over the other, Delaware simply offers them all. What is to prevent Delaware from doing the same with a general business corporation statute?

To some extent, this is already happening. Corporate law offers alternative default terms in various areas, and this "menu" approach (Ayres, 2005) is becoming increasingly widespread. The choice of a staggered board or cumulative voting are long-familiar examples. And more recently we see a variety of new opt-in and opt-out rules, including various antitakeover provisions such as the fair price statutes already discussed, or 
Delaware's provision for opting out of monetary liability for breach of the duty of care. We are beginning to develop some useful wisdom as to whether it is better to structure an alternative as an opt-in or an opt-out provision (Listokin, 2005). We could use more wisdom, however, on the number and types of alternatives that should be offered.

The delegated contracting view underlines the difference between two different types of statutory alternatives. First, there are choices offered on a term-by-term basis, such as the choice of a fair price provision. Second, there are choices between whole systems of provisions, such as the choice between forming the firm under a business corporation statute or under an LLC statute (or under Delaware's business corporation statute, as opposed to California's business corporation statute). It is also conceivable to have intermediate approaches in which a set of alternative terms is linked together, such as providing the option to adopt something like the British City Code rules on takeovers, which limit both the actions of potential acquirers (the mandatory bid rule) and the actions of the company's managers (no defensive tactics without shareholder approval). In general terms, the first approach seems most appropriate when there is uncertainty as to what is the most efficient rule. The second approach, in contrast, seems most appropriate where firms differ substantially in their ownership structure or their line of business (e.g., a mutual fund versus an industrial firm). The intermediate approach, in turn, could serve either purpose.

\section{Conclusion}

The law of business organizations is today going simultaneously in two different directions. At one end, principally in the realm of the closely held or special-purpose firm, the law is becoming increasingly contractual. Here, at the limit, organizational law simply offers the asset partitioning that defines creditors' rights, and leaves all relationships among the owners and managers of the assets to private design. At this end, organizational law is beginning to form a continuum with the law of commercial contracting, and legal entities are becoming just security interests. At the other end, in the realm of the generalpurpose public company, organizational law, in contrast, looks highly regulatory and seems to resist contractualization. Indeed, it seems to be becoming rather less contractual, as the securities laws, stock exchange listing rules, and the Sarbanes-Oxley Act increasingly dictate the permissible structures. 
The apparent reason for the divergence is that the increased sophistication in financial contracting that is driving contractualization at the one end has not been matched by progress in solving the problems of adaptive collective governance that drive the other end. As a consequence, it seems likely that the charters of public companies will continue to be written by the visible hand of government for some time to come.

\section{References}

Ayres, Ian. 1992. "Making a Difference: The Contractual Contributions of Easterbrook and Fischel," 59 University of Chicago Law Review 1391-1420. . 2005. "Regulating Menus." Yale Law School Working Paper.

Ayres, Ian, and Robert Gertner. 1989. "Filling Gaps in Incomplete Contracts: An Economic Theory of Default Rules," 99 Yale Law Journal 87-130.

Black, Bernard S. 1990. "Is Corporate Law Trivial? A Political And Economic Analysis," 84 Northwestern University Law Review 542-97.

Daines, Robert. 2002. "The Incorporation Choices of IPO Firms," 77 New York University Law Review 1559-1610.

Daines, Robert, and Michael Klausner. 2001. "Do IPO Charters Maximize Firm Value? Antitakeover Protection in IPOs," 17 Journal of Law, Economics \& Organization 83-120.

Dammann, Jens, and Henry Hansmann. 2005. "Extraterritorial Courts for Corporate Law,” ECGI-Law Working Paper 43/2005.

Davis, Kevin. Forthcoming. "The Role of Nonprofits in the Production of Boilerplate," Michigan Law Review.

Easterbrook, Frank H., and Daniel R. Fischel. 1989. "The Corporate Contract," 89 Columbia Law Review 1416-48.

Gordon, Jeffrey. 1989. "The Mandatory Structure of Corporate Law," 89 Columbia Law Review 1549-98.

Hadfield, Gillian, and Eric Talley. 2004. "On Public versus Private Provision of Corporate Law." University of South Carolina Law and Economics Research Paper 04-18.

Hansmann, Henry. 1996. The Ownership of Enterprise. Cambridge, MA: Harvard University Press.

Hansmann, Henry, and Ugo Mattei, 1998. "The Functions of Trust Law: A Comparative Legal and Economic Analysis," 73 New York University Law Review 434-79.

Hansmann, Henry, and Reinier Kraakman. 2000. "The Essential Role of Organizational Law," 110 Yale Law Journal 387-440.

Hansmann, Henry, Reinier Kraakman, and Richard Squire. 2005. "The New Business Entities in Evolutionary Perspective," 2005 Illinois Law Review 5-14. . Forthcoming. "Law and the Rise of the Firm," Harvard Law Review. 
Kahan, Marcel. 1995. "The Qualified Case against Mandatory Terms in Bonds," 89 Northwestern University Law Review 565-622.

Kahan, Marcel, and Michael Klausner. 1993. “Antitakeover Provisions in Bonds: Bondholder Protection or Management Entrenchment?" 40 UCLA Law Review 931-81.

1997. "Standardization and Innovation in Corporate Contracting (or 'The Economics of Boilerplate')," 83 Virginia Law Review 713-70.

Klausner, Michael. 1995. "Corporations, Corporate Law, and Networks of Contracts," 81 Virginia Law Review 757-852.

Listokin, Yair. 2005. "What Do Corporate Default Rules and Menus Do? An Empirical Examination." Yale Law School Working Paper.

Romano, Roberta. 1993. The Genius of American Corporate Law. Washington, DC: American Enterprise Institute.

Sitkoff, Robert. 2005. “Trust as 'Uncorporation': A Research Agenda," 2005 Illinois Law Review 31-48.

Thomsen, Steen. 2004. "Foundation Ownership and Financial Performance: Do Companies Need Owners?" 18 European Journal of Law and Economics 343-64.

Williamson, Oliver. 1976. "Franchise Bidding for Natural Monopolies-In General and with Respect to CATV," 7 Bell Journal of Economics 73-104. 